UNITED STATES DEPARTMENT OF THE INTERIOR

GEOLOGICAL SURVEY

A Description of Colored Gravity and Terrain

Maps of the Southwestern Cordillera

by

Richard W. Saltus

U.S. Geological Survey

Denver, Colorado 80225

Open-File Report 84-95

1984

This report is preliminary and has not been reviewed for conformity with U.S. Geological Survey editorial standards.

Any use of trade names is for descriptive purposes only and does not imply endorsement by the USGS. 


\section{A Description of Colored Gravity And Terrain Maps of the Southwestern Cordillera}

by

Richard W. Saltus

INTRODUCTION

Colored gravity and terrain maps of the Southwestern Cordillera covering California, Nevada, and portions of Utah and Arizona, have been prepared using an Applicon Color plotter. Colored copies of these maps are included in this report. Standard 2" $x$ 2" color slides of these maps are available from the U.S. Geological Survey Photo Library (Mail Stop 914, Box 25046, Denver Federa1 Center, Denver, C0, 80225, telephone 303/234-4004). When ordering s1ides from the library, refer to the open-file number of this report.

The gravity maps were prepared as part of regional studies of the Basin and Range Province and to extend the California Isostatic map (Roberts and others, 1981). The 30 maps fall into six classifications:

1) Digital terrain (1 map)

2) Wavelength filtered terrain (6 maps)

3) Complete Bouguer anomaly gravity ( 3 maps)

4) Isostatic residual gravity (the result of removing an isostatic regional gravity surface from the complete Bouguer anomaly, 7 maps)

5) Isostatic regional gravity (a smooth surface based on the calculated gravity effect of the crustal root required to provide complete local isostatic compensation of topography, 7 maps)

6) Wavelength filtered Bouguer gravity (6 maps)

This report supercedes Open-File Report 82-839 (Saltus, 1982) which contained only the maps shown in figures 8 and 11.

THE DATA SETS

1. Gravity Data

The gravity maps are based on about 100,000 gravity stations. This includes about 64,000 observations in California (Snyder and others, 1981a, $1981 \mathrm{~b})$ which had to be converted to the International Gravity Standardization Net of 1971 (Morel1i, 1974) and reduced using the 1967 Geodetic Reference System formula for theoretical gravity (International Association of Geodesy, 1971) in order to agree with the Nevada data. In Nevada, data from the following ten $1^{\circ} \times 2^{\circ}$ degree quadrangles were used:

1) Caliente (Healey and others, 1981)

2) Death Valley (Healey and others, 1980)

3) Goldfield (Healey and others, 1980)

4) Kingman (Bracken and Kane, 1983)

5) Las Vegas (Kane and others, 1979)

6) Lund (Bol and others, 1983)

7) Millett (Erwin and Bittleston, 1977)

8) Reno (Erwin and Berg, 1977) 
9) Tonopah (Healey and others, 1981)

10) Walker Lake (D. Plouff, personal commun.).

Data for the remainder of Nevada, Utah, and Arizona are from T. G. Hildenbrand, U.S. Geological Survey, Denver, and consist mostly of Department of Defense (DOD) data available through the National Oceanic and Atmospheric Administration (NOAA) Data Center. (NOAA, National Geophysical and Solar Terrestrial Data Center, Boulder, CO 80303).

2. Terrain Data

The digital terrain data are also available from NOAA in Boulder. The data are a subset of 5-minute $x$ 5-minute average elevation data covering North America. The data are described in U.S. Deptartment of Commerce Data Announcement $1980 \mathrm{SE}-\mathrm{U}$.

A FORTRAN gridding program (Webring, 1981), based on minimum curvature was used to interpolate and extrapolate both the gravity and terrain data to a square grid with a $5 \times 5 \mathrm{~km}$ grid interval. The gravity and terrain data were projected using the Albers Conic Equal-Area projection with standard parallels for the U.S. (latitude $29.5^{\circ} \mathrm{N}$, latitude $45.5^{\circ} \mathrm{N}$ ). A central meridian of longitude $96^{\circ} \mathrm{W}$ was used. The gridded data were plotted using Applicon Incorporated proprietary color sof twa re.

DESCRIPTION OF THE MAPS

Digital Terrain Map of the Southwestern Cordillera (Figure 1)

The NOAA 5 minute data set was contoured at 250 meter intervals. The color contours range from -250 to 4,000 meters. Blue colors represent the lower elevations and red colors represent the higher elevations.

Wavelength Filtered Terrain Maps of the Southwestern Cordillera (6 maps, Figures 2-7)

A fast Fourier transform filtering program by Robert Simpson, USGS, Menlo Park (written communication) was used to select long wavelengths from the digital terrain data. The long wavelength data were subtracted from the terrain map to produce the short wavelength map. This low pass filter used a simple rectangular window in the frequency domain, modified so that the gain of the filter drops from one to zero along a ramp centered at the cut-of $f$ wavelength. Three sets of filtered maps were made with wavelength cut-offs of 100,150 , and $250 \mathrm{~km}$. The parameters for each map are listed in table 1 .

Table 1

Figure

2

3

4

5

6

7

wavelengths $\mathrm{km}$

$>100$

$\begin{array}{cc}>150 & >250 \\ 125-175 & 200-300 \\ 250 & 250\end{array}$

$<100$

$<150$

$<250$

linear ramp $\mathrm{km}$

contour interval meters

$\begin{array}{ccc}80-120 & 125-175 & 200-300 \\ 250 & 250 & 250\end{array}$

80-120

125-175

200-300

For a discussion of wavelength filtering see Simpson and others (1982). 
Bouguer Gravity Anomaly Maps of the Southwestern Cordillera ( 3 maps, Figures 8,9 , and 10)

Bouguer anomalies were calculated using the Geodetic Reference System 1967 formula (International Association of Geodesy, 1971) and tied to the IGSN 71 dagtum (Morel1i, 1974) with reduction densities of $2.67,2.5$, and 2.3 $\mathrm{g} / \mathrm{cm}^{3}$. Terrain corrections have been calculated using a program by Plouff (1977). Estimated error in the Bouguer gravity value is less than 2.0 milligals (mGal). The terrain corrections were calculated with a Bouguer
reduction density of $2.67 \mathrm{~g} / \mathrm{cm}^{3}$ and then converted to $2.5 \mathrm{~g} / \mathrm{cm}^{3}$ and $2.3 \mathrm{~g} / \mathrm{cm}^{3}$ using the formula

$$
\mathrm{TC}_{\mathrm{p} 2}=\mathrm{TC}_{2.67} \times \frac{\mathrm{p} 2}{2.67}
$$

(where $\mathrm{p} 2$ is the alternate Bouguer density, $\mathrm{TC}_{\mathrm{p} 2}$ is the terrain correction for Bouguer density $\mathrm{p} 2$ and $\mathrm{TC}_{2.67}$ is the terrain correction for density 2.67 $\left.\mathrm{g} / \mathrm{cm}^{3}\right)$. This method is not correct for stations near the ocean, as terrain corrections for the variation of the ocean bottom from sea level were made using a density of $1.67 \mathrm{~g} / \mathrm{cm}^{3}\left(2.67 \mathrm{~g} / \mathrm{cm}^{3}\right.$ minus the the density of sea water, $\left.1.0 \mathrm{~g} / \mathrm{cm}^{3}\right)$. For these areas the correct conversion would be

$$
\mathrm{TC}_{\mathrm{p} 2}=\mathrm{TC}_{\text {ocean }} \times \frac{(\mathrm{p} 2-1.0)}{1.67}
$$

The error for a large oceanic terrain correction, e.g. $20 \mathrm{mGal}$, would be 1.66 mGal. Since the correction is added to the gravity value, this means that coastal Bouguer values will be slightly high. This inaccuracy is too small, however, to substantially alter the $20 \mathrm{mGal}$ contours, even at the shore line.

The color contours of the maps range from $-280 \mathrm{mGal}$ to $100 \mathrm{mGal}$ at an interval of $20 \mathrm{mgal}$, with blue colors representing areas of low Bouguer gravity values and red colors showing areas of high Bouguer gravity values.

Isostatic Residual Gravity Maps of the Southwestern Cordillera (7 maps, Figures 11-17)

Each of these maps is the result of subtracting an isostatic regional surface (figures 18-24) from a complete Bouguer anomaly map (figures 8-10).

Isostatic corrections were computed using a FORTRAN program (Simpson, written communication) based on the Airy-Heiskanen model of compensation (Heiskanen and Meinesz, 1958, p. 135-137) using the parameters shown in table 2. The isostatic residual values range from $-70 \mathrm{mGal}$ to $+70 \mathrm{mGal}$ with a contour interval of $10 \mathrm{mgal}$. Blue colors represent areas of low residual gravity and reds show areas of high residual gravity. The reference to Moho in the figure captions refers simply to the bottom of the root. This surface will not necessarily agree with the seismically determined Moho. 
Table 2

\begin{tabular}{|c|c|c|c|c|c|c|c|}
\hline Residual Map figure & 11 & 12 & 13 & 14 & 15 & 16 & 17 \\
\hline Regional Map figure & 18 & 19 & 20 & 21 & 22 & 23 & 24 \\
\hline Crustal Density: $\quad \mathrm{g} / \mathrm{cm}^{3}$ & 2.67 & 2.67 & 2.67 & 2.67 & 2.67 & 2.5 & 2.3 \\
\hline Compensation Depth: km & 25 & 25 & 25 & 25 & 30 & 25 & 25 \\
\hline $\begin{array}{l}\text { Density Contrast at } \\
\text { compensation depth: } \mathrm{g} / \mathrm{cm}^{3}\end{array}$ & 0.4 & 0.2 & 0.3 & 0.6 & 0.4 & 0.4 & 0.4 \\
\hline
\end{tabular}

These maps show the gravitational attraction of the crustal root required by the model to provide complete local isostatic compensation of topography.

Isostatic corrections were computed using the parameters shown in table 2. The isostatic regional values are contoured with the same color scale as the Bouguer maps (range -280 to $+100 \mathrm{mGal}, 20 \mathrm{mGal}$ interval).

Wavelength Filtered Bouguer Gravity Maps of the Southwestern Cordillera (6 maps, Figures 25-30)

Three sets of wavelength filtered Bouguer maps were made using the same procedure as for the filtered terrain maps. The longer wavelength maps are contoured using the same color scale as the Bouguer maps (range -280 to t100 $\mathrm{mGal}, 20 \mathrm{mGal}$ interval). The short wavelength maps are contoured using the same color scale as the isostatic residual maps (range -70 to $+70 \mathrm{mGal}, 10$ mGal interval). The parameters for each map are shown in Table 3. For a discussion on effects of wavelength filtering see Simpson and others (1982).

Table 3

$\begin{array}{lcccccc}\text { Figure } & 25 & 26 & 27 & 28 & 29 & 30 \\ \text { wavelength cutoff } \mathrm{km} & >100 & >150 & >250 & <100 & <150 & <250 \\ \begin{array}{l}\text { linear ramp km } \\ \text { contour interval mGal }\end{array} & 80-120 & 125-175 & 200-300 & 80-120 & 125-175 & 200-300 \\ & 20 & 20 & 20 & 10 & 10 & 10\end{array}$

Discussion and Interpretation

This series of maps was inspired by a desire to compare the results of wavelength filtering vs. isostatic modeling in the analysis of the Bouguer gravity map. The wavelength filter is a somewhat arbitrary mathematical surface fitting process, while the isostatic regional results from a model of compensation designed to explain physical observations. That the two methods are comparable is evident from the basic similarity of figures 18 (isostatic regional density $=2.67 \mathrm{~g} / \mathrm{cm}^{3}$, contrast $=0.4 \mathrm{~g} / \mathrm{cm}^{3}$, compensation depth $=25$ $\mathrm{km}$ ) and 27 (filtered Bouguer gravity containing only wavelengths longer than $250 \mathrm{~km}$ ). This correlation indicates the extent to which the gravitational effect of the Airy root accounts for wavelengths longer than $250 \mathrm{~km}$ of the Bouguer gravity field.

However, there are important and interesting differences between the two methods. Although the isostatic regional (figure 18) resembles the $>250 \mathrm{~km}$ wavelength map (figure 27), it has areas which contain shorter wavelength 
features as well. For example, the shape of the regional field in northcentral California looks more like the same area of the $>150 \mathrm{~km}$ wavelength map (figure 26). Another example is southernmost California where the high coming in from Mexico on the regional map (figure 18) better resembles the same area on the $>100 \mathrm{~km}$ wavelength map (figure 25). The central Nevada low is not as deep in the regional map as in any of the long wavelength maps.

The differences are even more striking on the residual maps. Compare the $<250 \mathrm{~km}$ wavelength map (figure 30 ) with the isostatic residual map (figure 11). One of the most striking features of the $<250 \mathrm{~km}$ wavelength map is the series of parallel alternating highs and lows that extend east of north from the California coast to the Nevada-Utah state line. Except for the westernmost low and high, these stripes have been interpreted (Kane and others, 1982) as parallel bands of felsic rock causing gravity lows and intervening bands of normal crust causing relative highs. Kane comments further (Kane and Godson, 1983) that the strike of these features paralle1 to the subducted oceanic plate prompts speculation that the pattern is related in some way to subduction.

These stripes are not so obvious on the isostatic residual map (figure 11). The westernmost low and high (the great valley low and the high associated with the west side of the Sierra Nevada) are still clear, although the north-south continuity of the high is rather vague. The remaining stripes which cross Nevada appear only as a residual of the symmetric central Nevada "Butterf1y" anomaly (Eaton and others, 1978, p. 78, Fig. 3-10) and do not show as much north-south extent as the stripes on the wavelength filtered map. Thus, based on the isostatic residual map one would be unlikely to postulate some relation between oceanic subduction of $f$ the California coast and the faint linearities suggested by the center and sides of the "Butterfly".

The isostatic map (figure 11) shows a prominent low in northwestern California which extends from Cape Mendocino east to the great valley. This low has been interpreted to "reflect the south edge of the Gorda plate where it is subducted eastward beneath the North American plate" (Jachens and Griscom, 1983). The proximity at the coast of the western edge of this gravity low to magnetic and seismic expressions of the plate in that region led Jachens and Griscom to associate this anomaly with the Gorda plate. On the $<250 \mathrm{~km}$ wavelength map, however, the low does not extend all the way to the coast. In addition, the eastern-most lobe of the low as shown on isostatic map ( $\mathrm{fig} .11$ ) is missing on the $<250 \mathrm{~km}$ wavelength map (figure 30). The use of the wavelength residual technique over the isostatic method could have led to a different interpretation in this case, just as in the case of the parallel stripe features previously mentioned.

In short, although many of the same basic features are enhanced by these two residual techniques, the differences in the residual maps can lead to very different interpretations. Because the isostatic technique is based on a physical model it is perhaps safer to attribute geologic interpretations to its anomalies. Thus, the isostatic residual map is probably a more useful starting point for quantitative modelling. However, care must be used in attaching significance to either model. Despite the stability of this isostatic model, it is still only a model with a uniform density contrast, crustal density, and compensation depth. Clearly, true isostatic compensation does not follow such simple rules. The wavelength filtering technique makes the assmption that the gravitational effects of near-surface masses (generally 
those of geologic interest) can be separated from those arising from larger and deeper features (such as the isostatic root system, whatever its structure may be) simply by separating wavelengths. This assumption, too, is clearly naive. The separation is not complete, some long wavelength anomalies can be caused by broad shallow features. Also, the amplitudes of short wavelength anomalies may be distorted by the removal of the long wavelengths.

Examination of the isostatic regional maps and their associated residual maps reveals the stability of the Airy model: despite variation of the model parameters to either end of a spectrum of reasonable crustal densities and density contrasts, the overall appearance of the residual map is preserved. The maximum change in value is about $20 \mathrm{mGal}$ in the depth of the central Nevada low. Therefore, uncertainties in the exact parameters for the isostatic model do not preclude its general usefulness.

The inverse correlation of wavelength filtered terrain (especially figure 4, with wavelengths longer than $250 \mathrm{~km}$ ), and the isostatic regional (figure 18 ) is inherent in the basic concept of isostatic compensation (the topographic surface load is in some sort of hydrostatic equilibrium). In this case, the shape of the supporting Airy root is based on the surface topography, and therefore, the isostatic regional shows some of the same longwavelength features as the wavelength filtered terrain maps (figures 2-4).

\section{References Cited}

Bo1, A. J., Snyder, D. B., Healey, D. L., and Saltus, R. W., 1983, Principle facts, accuracies, sources, and base station descriptions for 3672 gravity stations in the Lund and Tonopah $1^{\circ} \times 2^{\circ}$ quadrangles, Nevada: U.S. Geological Survey Report, available from U.S. Department of Commerce National Technical Information Service, Springfield, VA 22161, NTISPB83-202671.

Bracken, Robert E., and Kane, Martin F., 1983, Principal facts for gravity stations in the Nevada portion of the Kingman $1^{\circ} \times 2^{\circ}$ quadrangle: U.S. Geological Survey Report, available from U.S. Department of Commerce Nationa1 Technical Information Service, Springfield, VA 22161, NTISPB84-103084.

Eaton, G. P., Wahl, R. R., Prostka, H. J., Mabey, D. R., and Kleinkopf, M. D., 1978, Regional gravity and tectonic patterns: Their relation to late Cenozoic ipeirogeny and lateral spreading in the western Cordillera, in Smith, R. B. and Eaton, G. P., eds., Cenozoic tectonics and regional geophysics of the western Cordillera: Geological Society of America Memoir 152, p. 51-92.

Erwin, J. W., and Berg, J. C., 1977, Bouguer gravity map of Nevada, Reno sheet: Nevada Bureau of Mines and Geology Map 58, scale 1:250,000.

Erwin, J. W., and Bittleston, E. W., 1977, Bouguer gravity map of Nevada, Millett sheet: Nevada Bureau of Mines and Geology Map 53, scale $1: 250,000$.

Healey, D. L., Snyder, D. B., and Wah1, R. R., 1981, Bouguer gravity map of Nevada, Tonopah sheet: Nevada Bureau of Mines and Geology Map 73, scale $1: 250,000$. 
Healey, D. L., Snyder, D. B., Wah1, R. R., and Currey, F. E., 1981, Bouguer gravity map of Nevada, Caliente sheet: Nevada Bureau of Mines and Geology Map 70, scale $1: 250,000$.

Healey, D. L., Wahl, R. R., and Currey, F. E., 1980, Bouguer gravity map of Nevada, Goldfield and Mariposa sheets: Nevada Bureau of Mines and Geology Map 68, scale 1:250,000.

Healey, D. L., Wahl, R. R., and 0liver, H. W., 1980, Bouguer gravity map of Nevada, Death Valley sheet: Nevada Bureau of Mines and Geology Map 69, scale $1: 250,000$.

Heiskanen, W. A., and Vening Meinesz, F. A., 1958, The earth and its gravity field: New York, McGraw-Hill, 459 p.

International Association of Geodesy, 1971, Geodetic Reference System 1967: International Association of Geodesy Special Publication, no. 3, $116 \mathrm{p}$.

Jachens, R. C., and Roberts, C. W., 1981, Documentation of a FORTRAN program, 'isocomp', for computing isostatic residual gravity: U.S. Geological Survey Open-File Report 81-574, 26 p.

Jachens, R. C., Roberts, C., and Griscom, Andrew, 1983, Three-Dimensional geometry of the Gorda plate beneath northern California: Journal of Geophysical Research, v. 88, p. 9375-9392.

Kane, M. F. and Godson, R. H., 1983, Features of the $250 \mathrm{~km}$ lowpass and highpass gravity maps of the United States, in Proceedings of the 1982 SEG Symposium, (in press).

Kane, M. F., Healey, D. L., Peterson, D. L., Kaufmann, H. E., and Reidy, D., 1979 , Bouguer gravity map of Nevada, Las Vegas Sheet: Nevada Bureau of Mines and Geology Map 61, scale 1:250,000.

Kane, M. F., Hildenbrand, T. G., Simpson, R. W., Godson, R. H., and Bracken, R. E., 1982, Crust and mantle structure of the conterminous United States from wavelength-filtered gravity data: Society of Exploration Geophysicists Technical Program, abstracts and biographies, Oct. 17-21, 1982, p. 232-234.

Morelli, C., (Ed.), 1974, The International Gravity Standardization Net 1971: International Association of Geodesy Special Publication, no. 4, $194 \mathrm{p}$.

Oliver, H. W., Saltus, R. W., Mabey, D. R., and Hildenbrand, T. G., 1982, Comparison of Bouguer anomaly and isostatic residual-gravity maps of the southwestern cordillera: Society of Exploration Geophysicists, meetings, Dallas, October, 1982, Program.

Plouff, Donald, 1977, Preliminary documentation for a FORTRAN program to compute gravity terrain corrections based on topography digitized on a geographic grid: U.S. Geological Survey Open-File Report 77-534, 45 p. 
Roberts, C. W., Jachens, R. C., and 01iver, H. W., 1981, Isostatic residual gravity map of California: U.S. Geological Survey Open-File Report 81573, scale $1: 750,000$.

Saltus, R. W., 1982, A description of Bouguer anomaly and isostatic residual colored gravity maps of the southwestern cordillera: U.S. Geological Survey Open-File Report 82-839, 7 p. including 2 color pages.

Simpson, R. W., Hildenbrand, T. G., Godson, R. H., and Kane, M. F., 1982, A description of colored gravity and terrain maps for the United States and adjacent Canada east of $104^{\circ}$ : U.S. Geological Survey Open-File Report 82-877.

Snyder, D. B., Roberts, C. W., Saltus, R. W., and Sikora, R. F., 1981a, Description of magnetic tape containing the principal facts of about 64,000 gravity stations in the state of California: available from U.S. Department of Commerce National Technical Information Service, Springfield, VA 22161, NTIS-PB82-168-279, 30 p.

Snyder, D. B., Roberts, C. W., Saltus, R. W., and Sikora, R. F., 1981b, Magnetic tape containing the principal facts of about 64,000 gravity stations in the state of California: available from U.S. Department of Commerce, National Technical Information Service, Springfield, VA 22161, NTIS PB82-168-287, 1 tape.

Webring, Michael, 1981, MINC: a gridding program based on minimum curvature: U.S. Geological Survey Open-File Report 81-1224, 41 p. 
\begin{tabular}{l}
10 \\
0 \\
1 \\
5 \\
$\infty$ \\
0 \\
$=$ \\
\hline \\
1 \\
5 \\
0 \\
0 \\
0 \\
0 \\
0 \\
0 \\
0 \\
0
\end{tabular}

N

(1)

כั

ㄴ
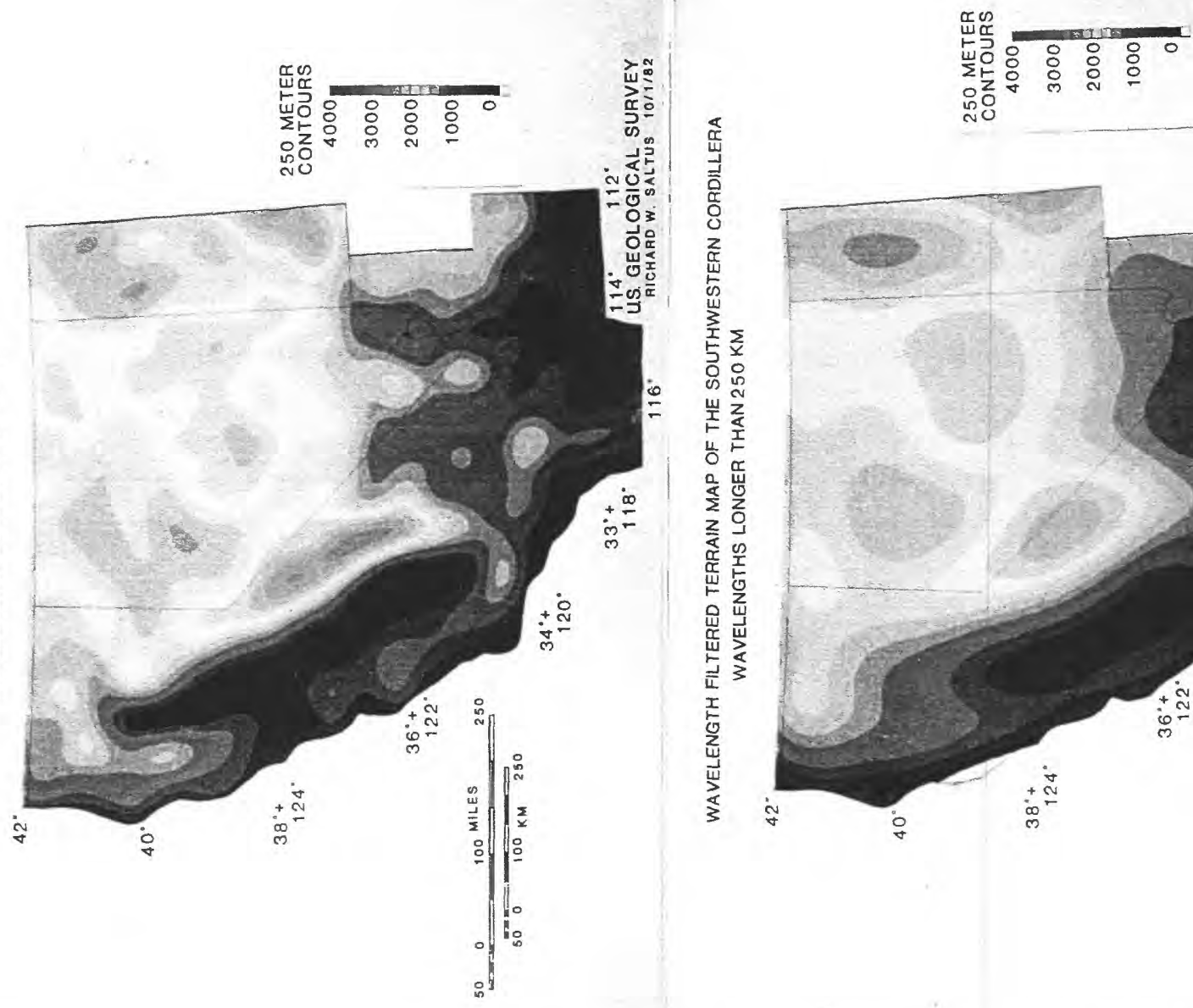

胥

造

空

똗

능

足皆

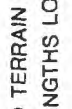

总崫

焉

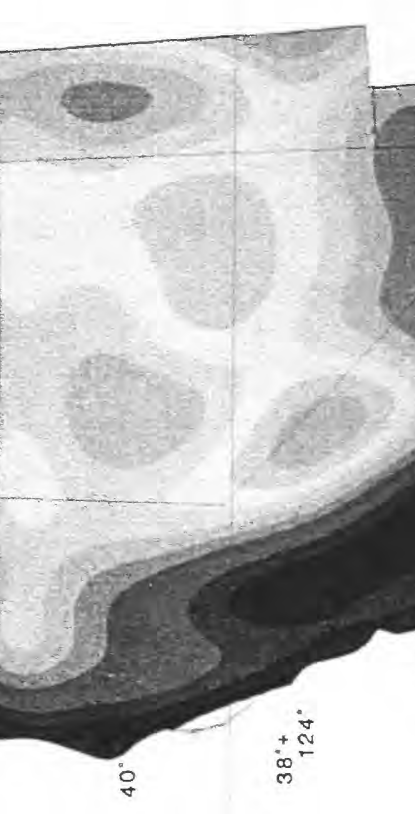

+
0
$\frac{2}{0}$
$\frac{1}{4}$
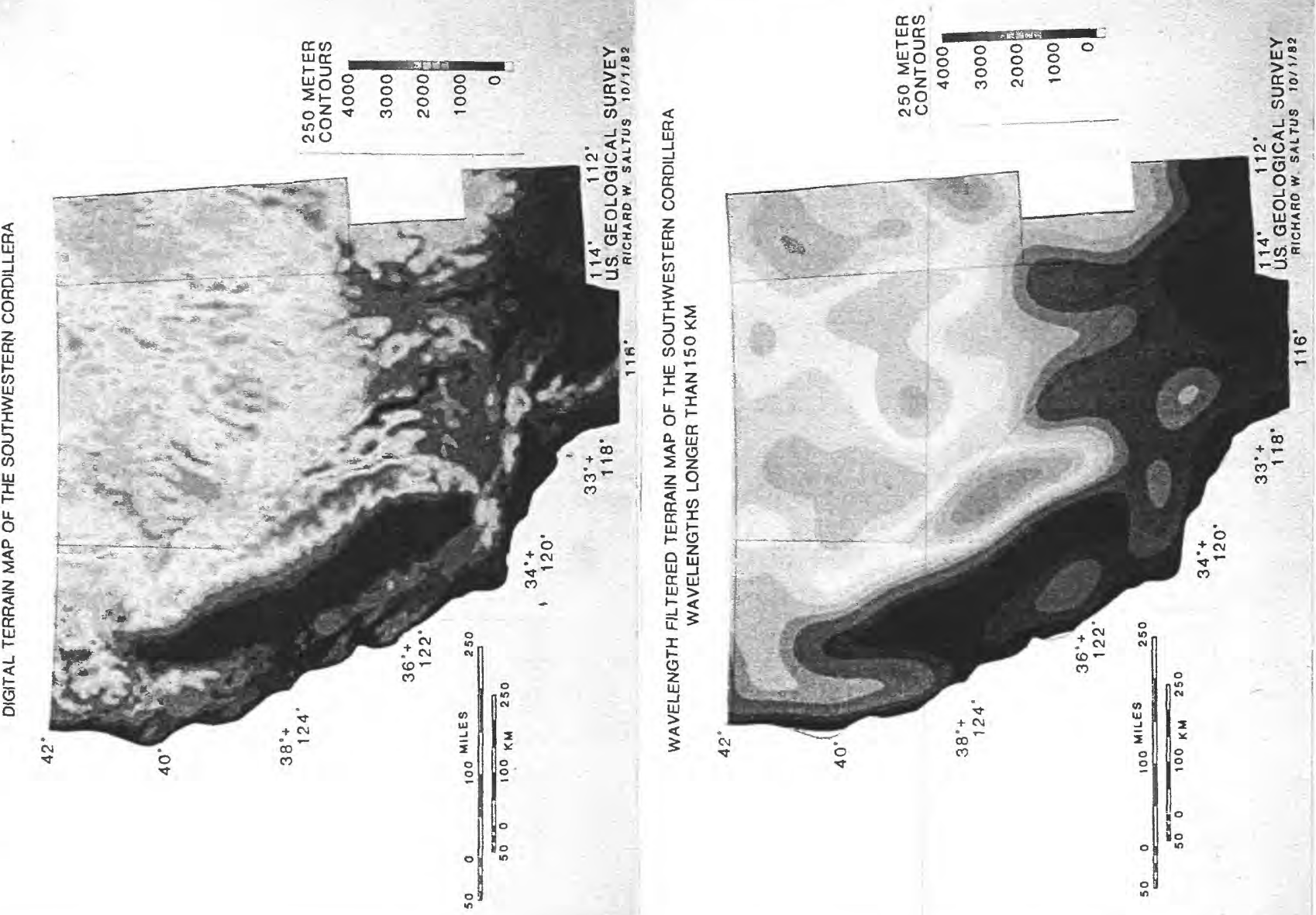

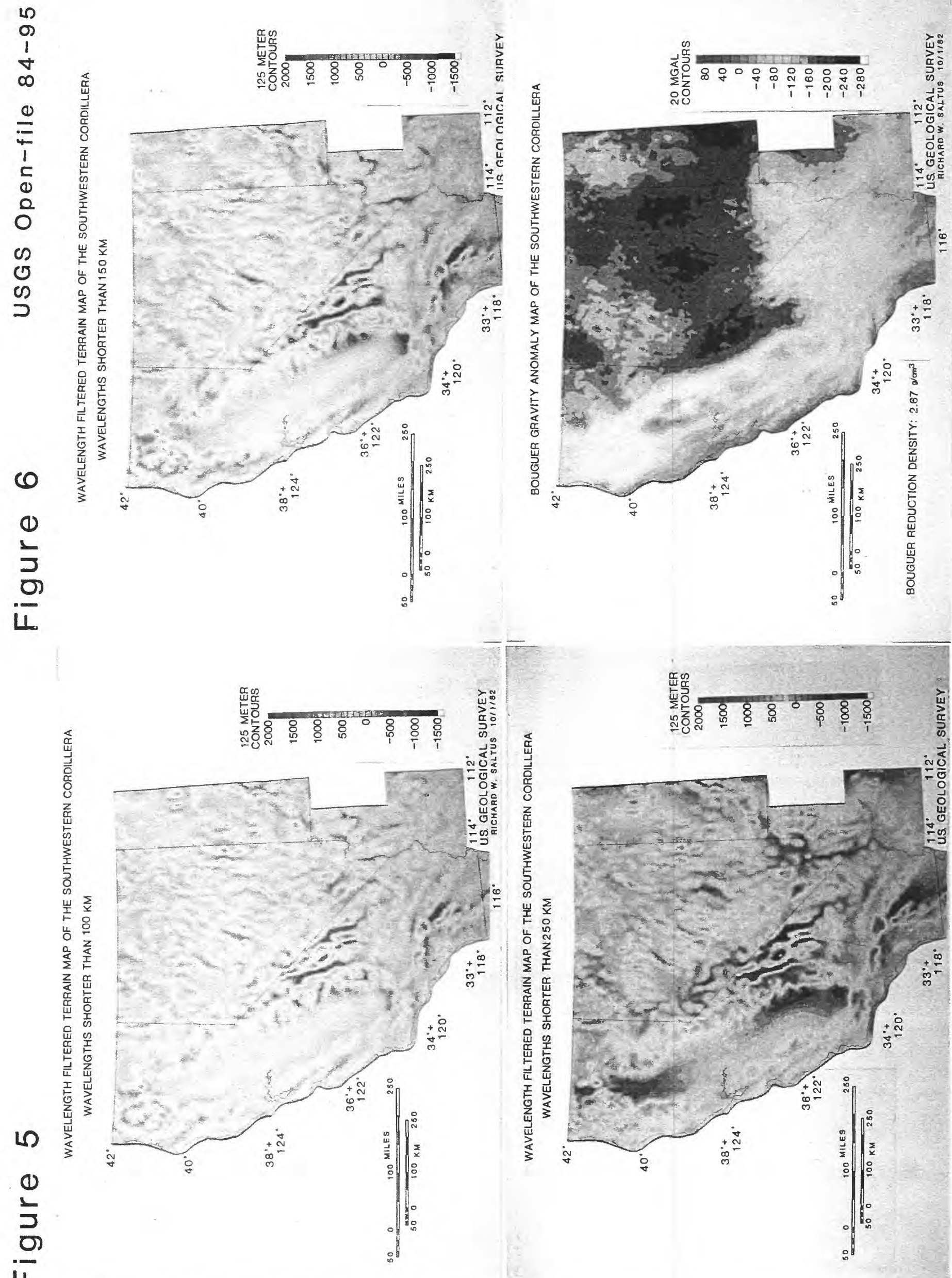

$\infty$
$\frac{1}{3}$
$\frac{5}{4}$ 

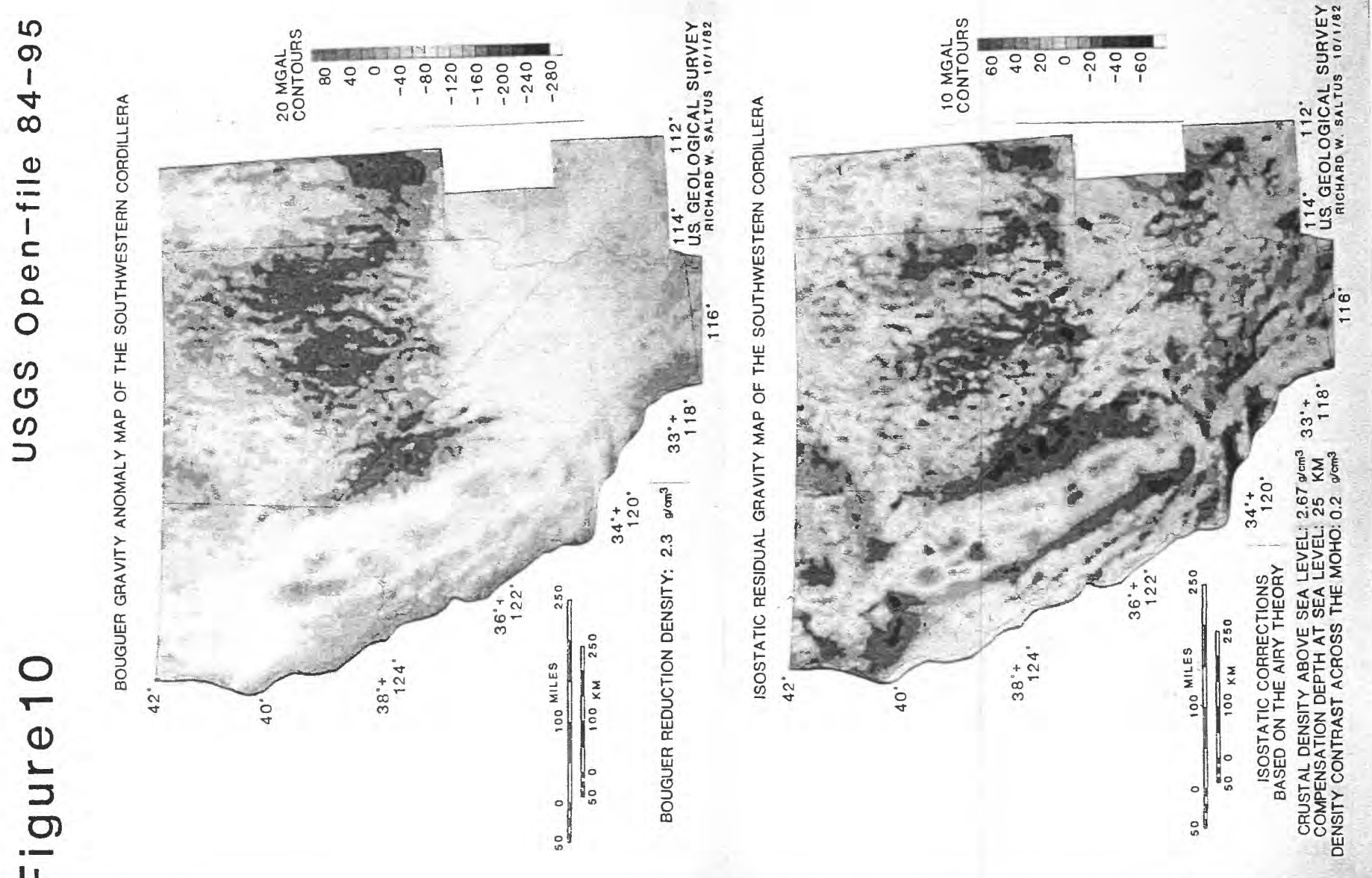

V
0
$\frac{1}{3}$
0
$\frac{1}{4}$
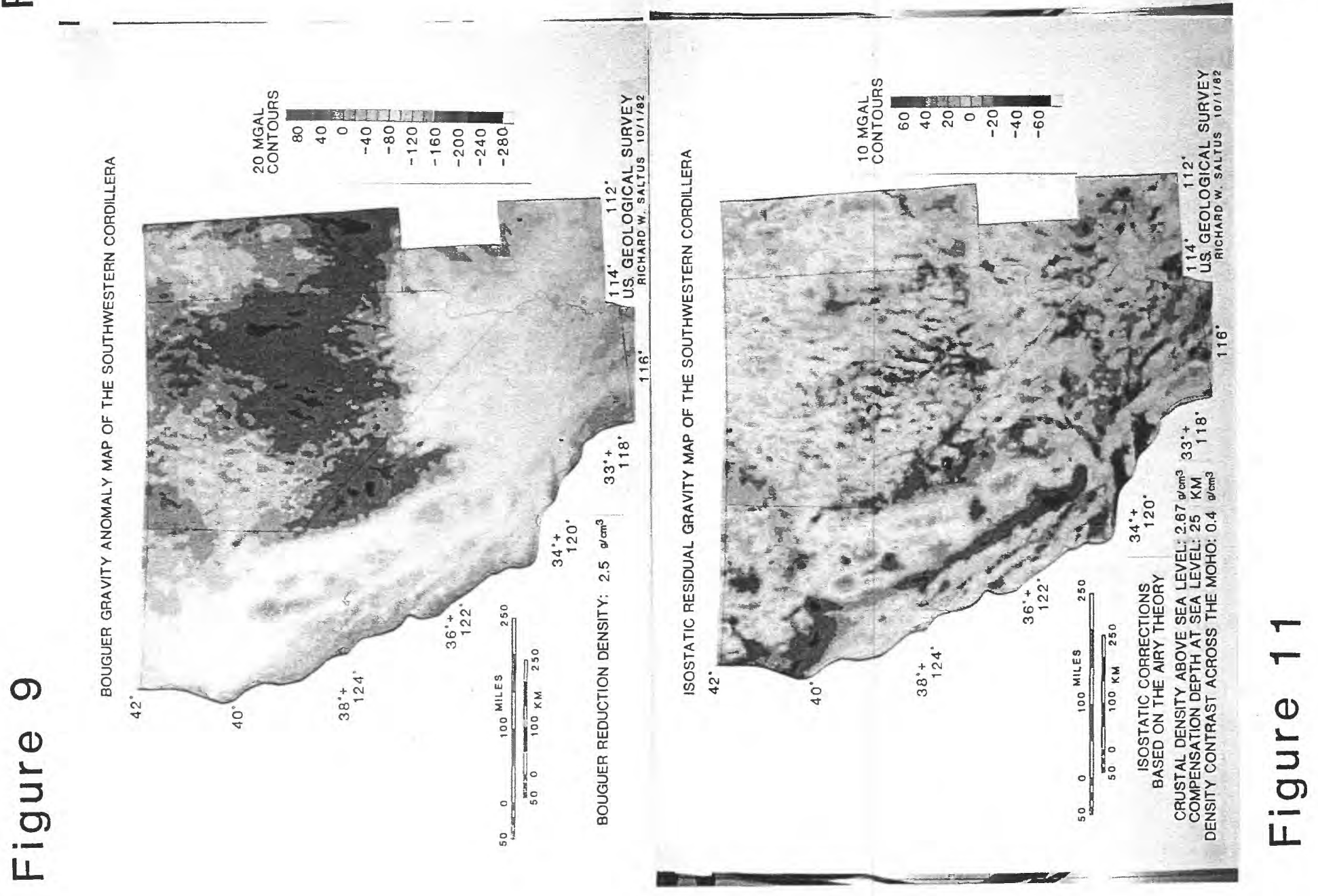

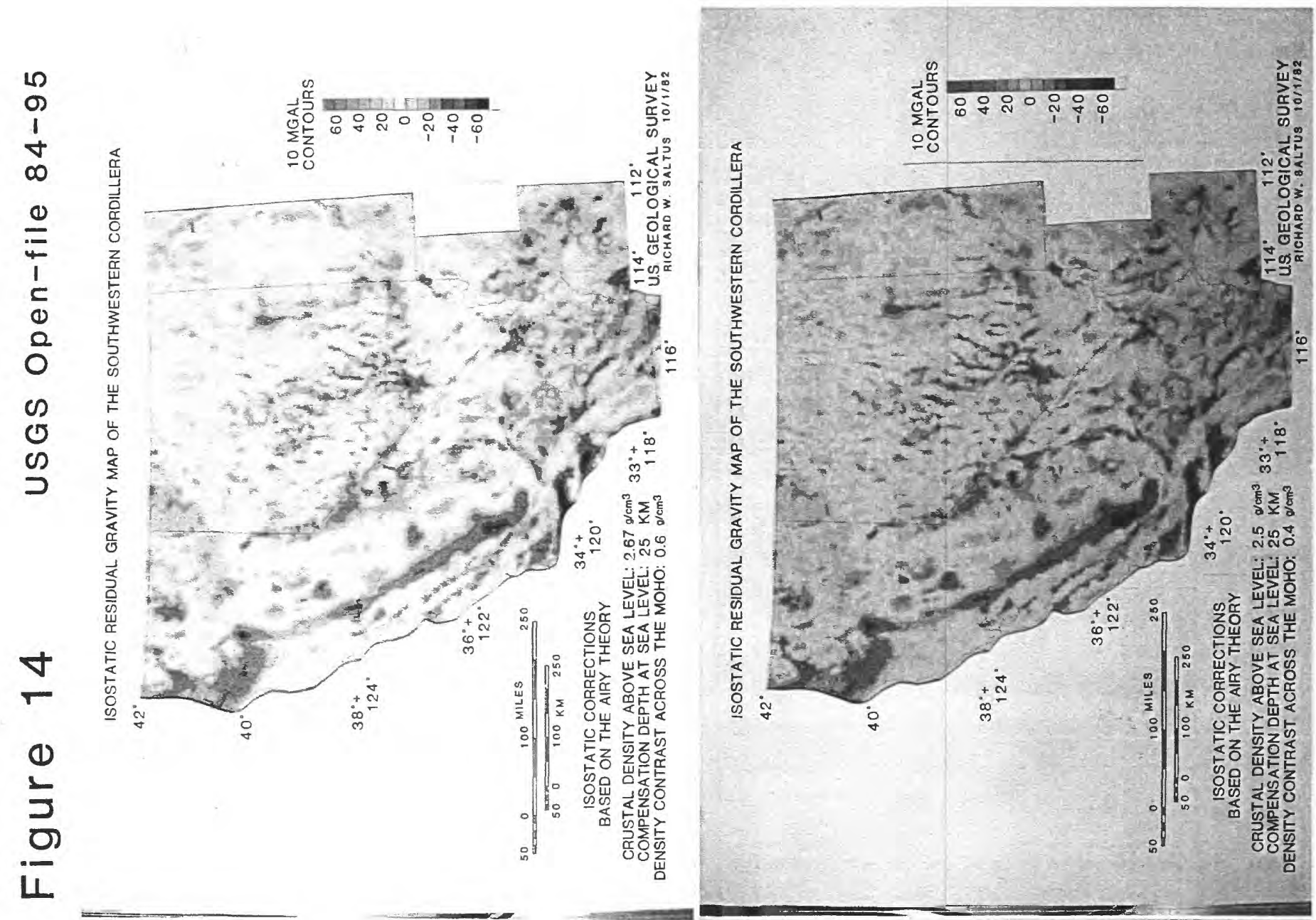

0
0
$\frac{1}{3}$
$\frac{9}{4}$
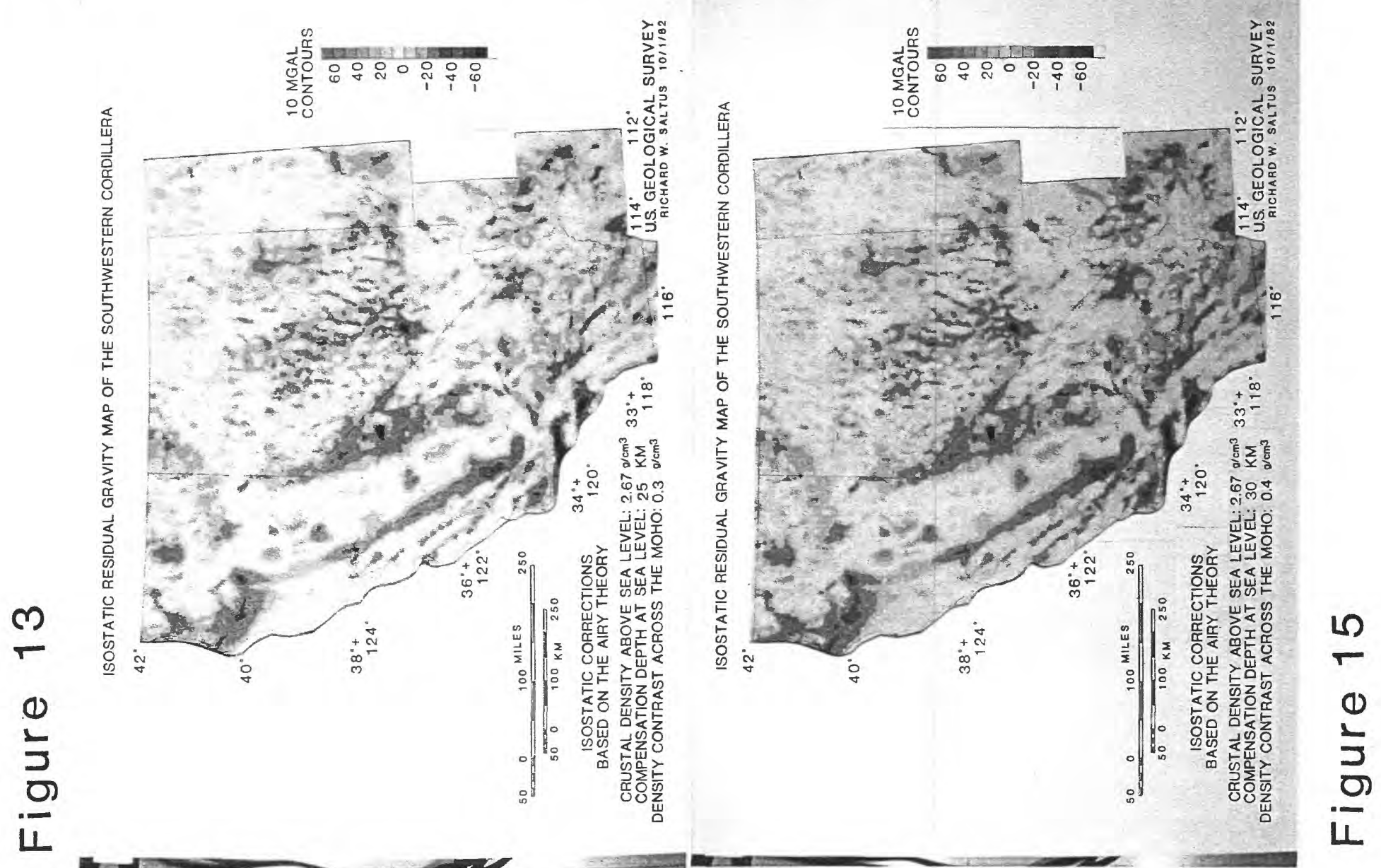

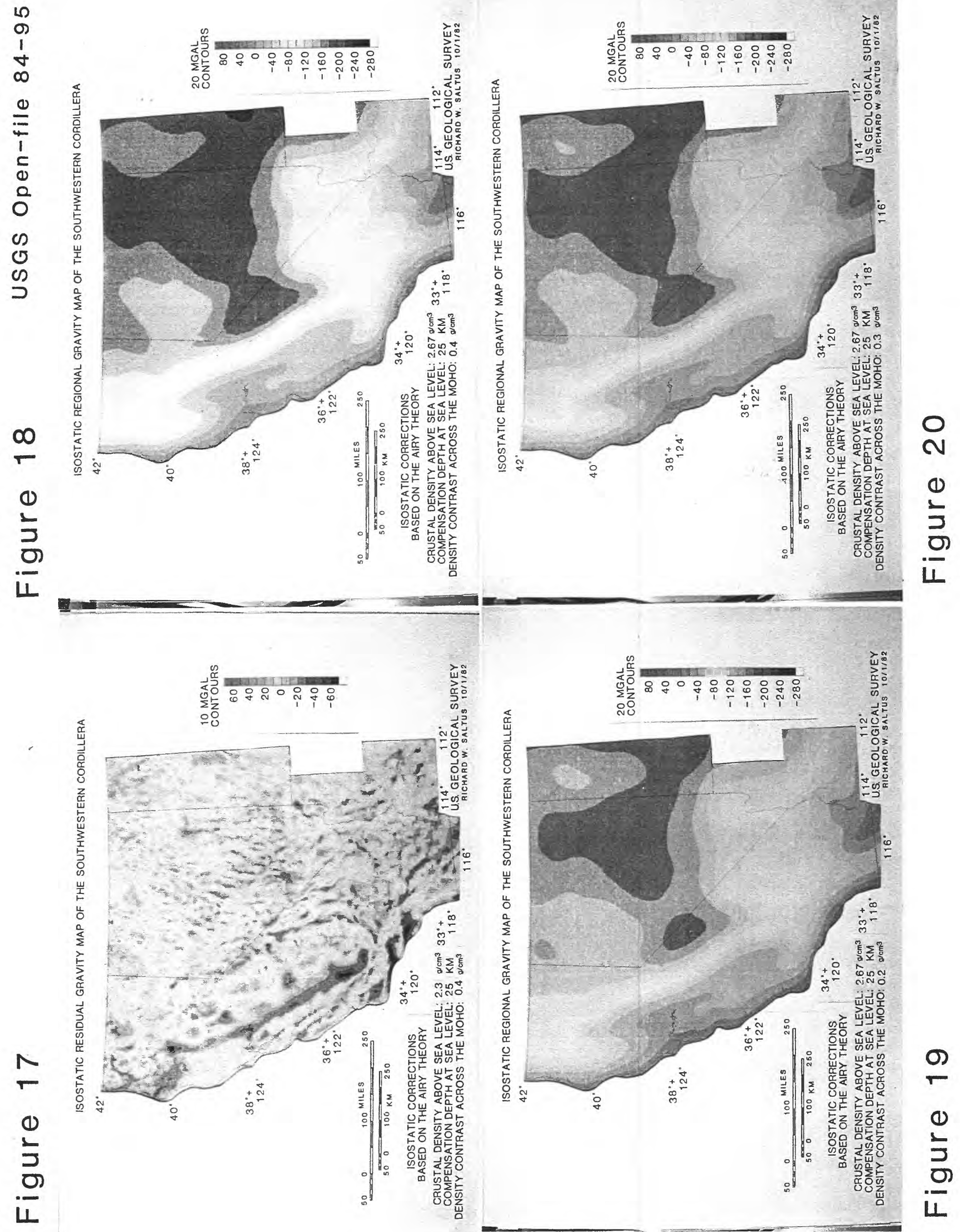


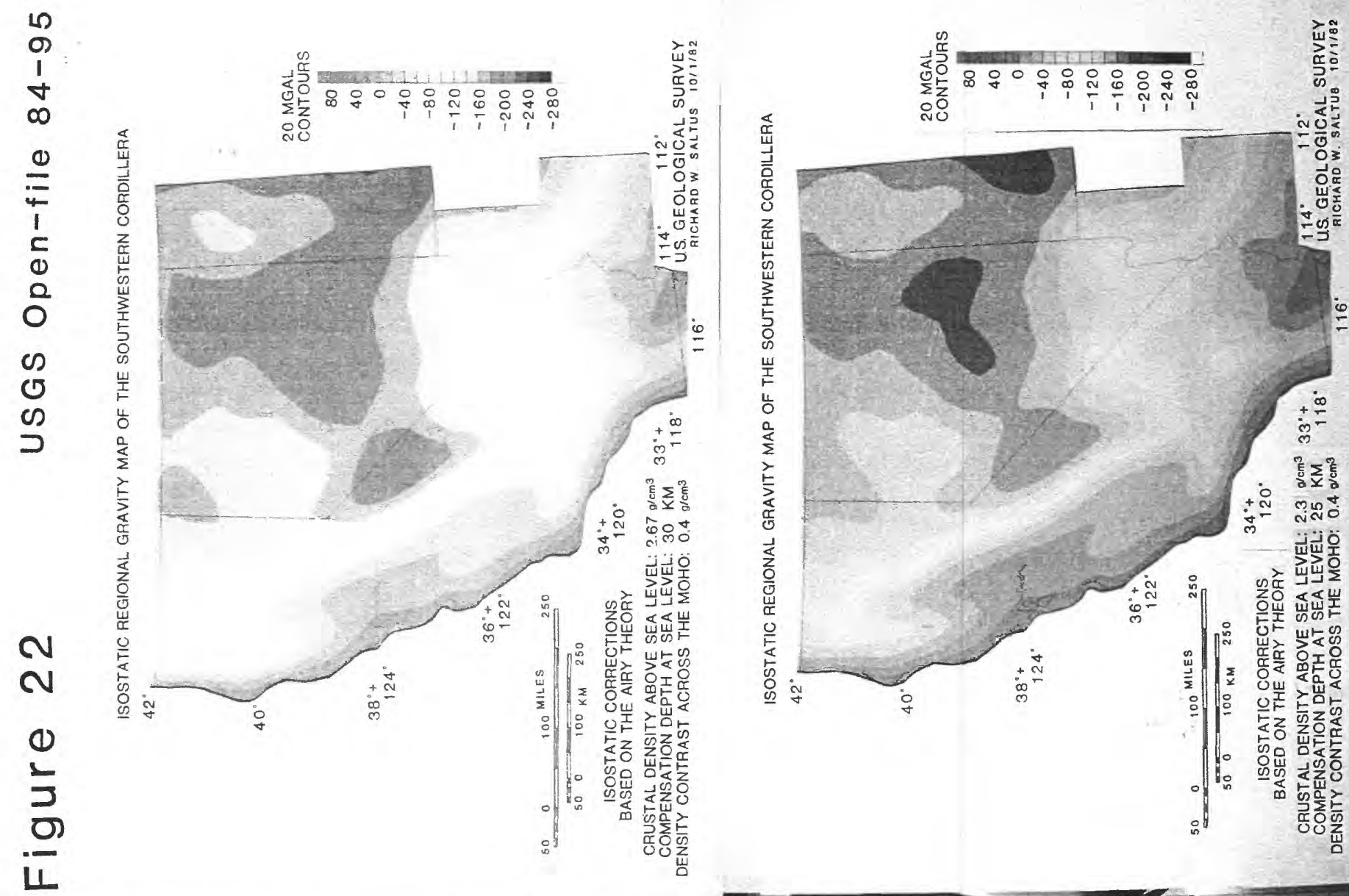

0
$\frac{1}{3}$
$\frac{1}{4}$
$\frac{2}{4}$

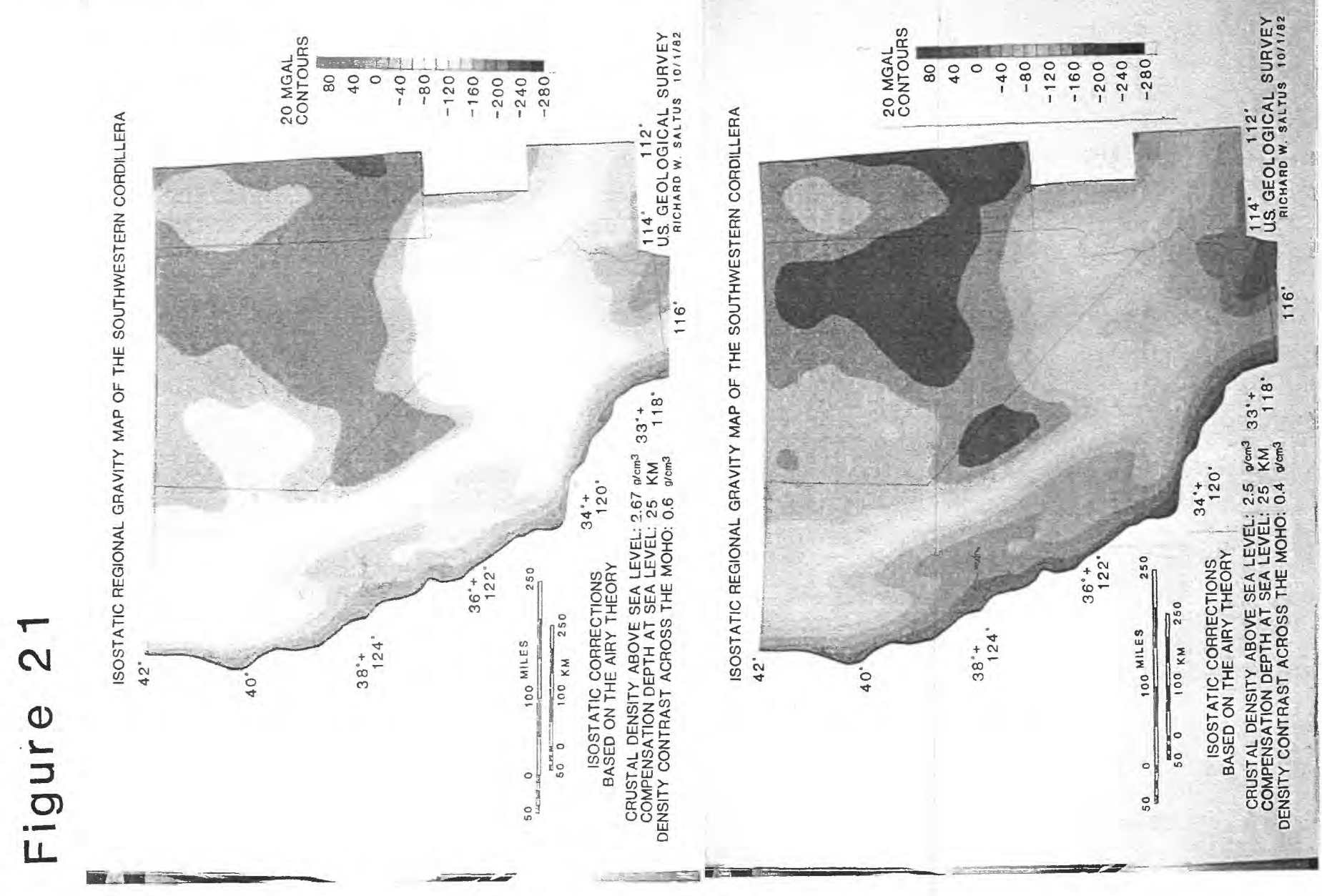




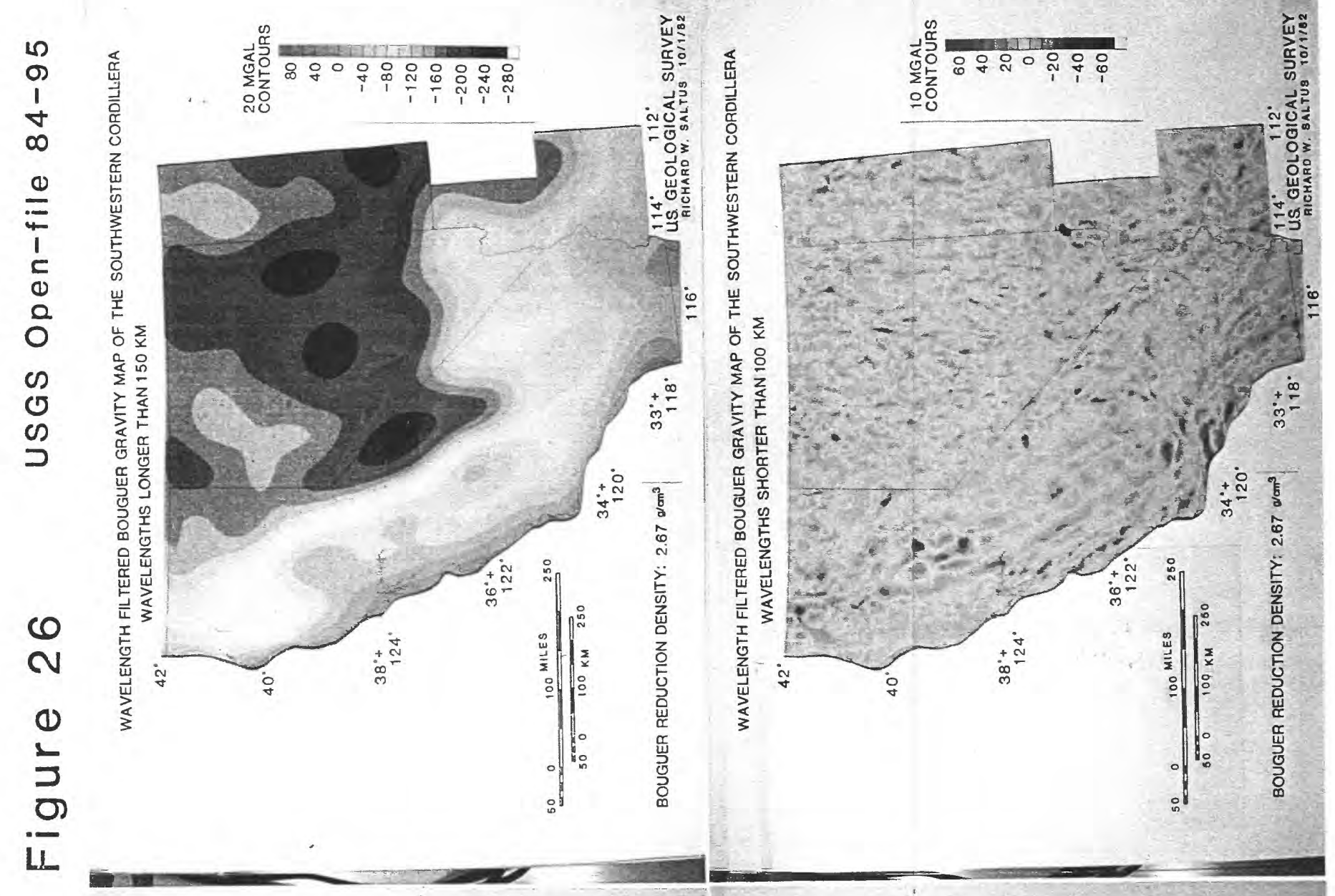

$\infty$
$\sim$
0
$\frac{1}{3}$
$\frac{0}{4}$

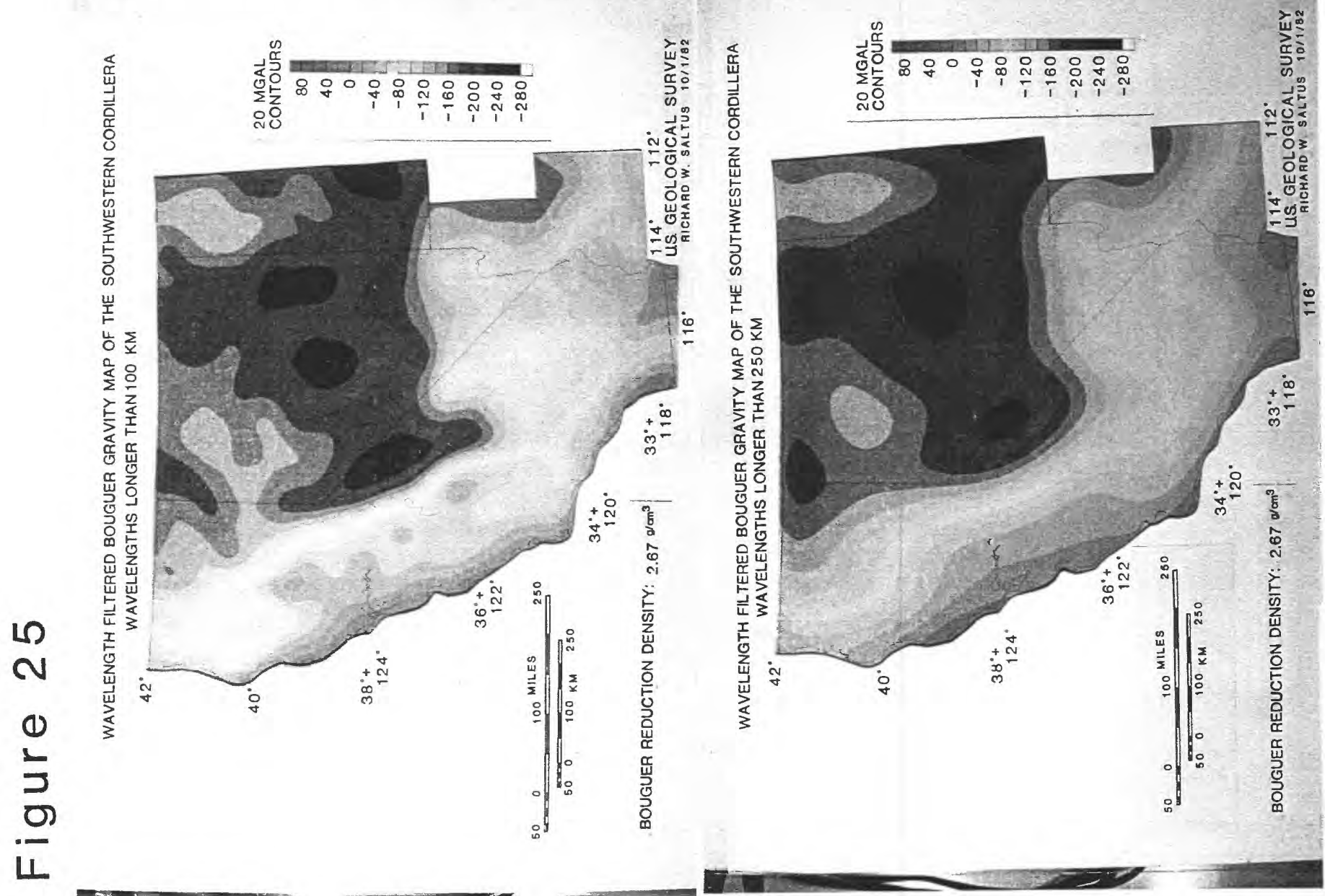

$N$
$\sim$
0
$\frac{1}{3}$
$\frac{0}{4}$ 


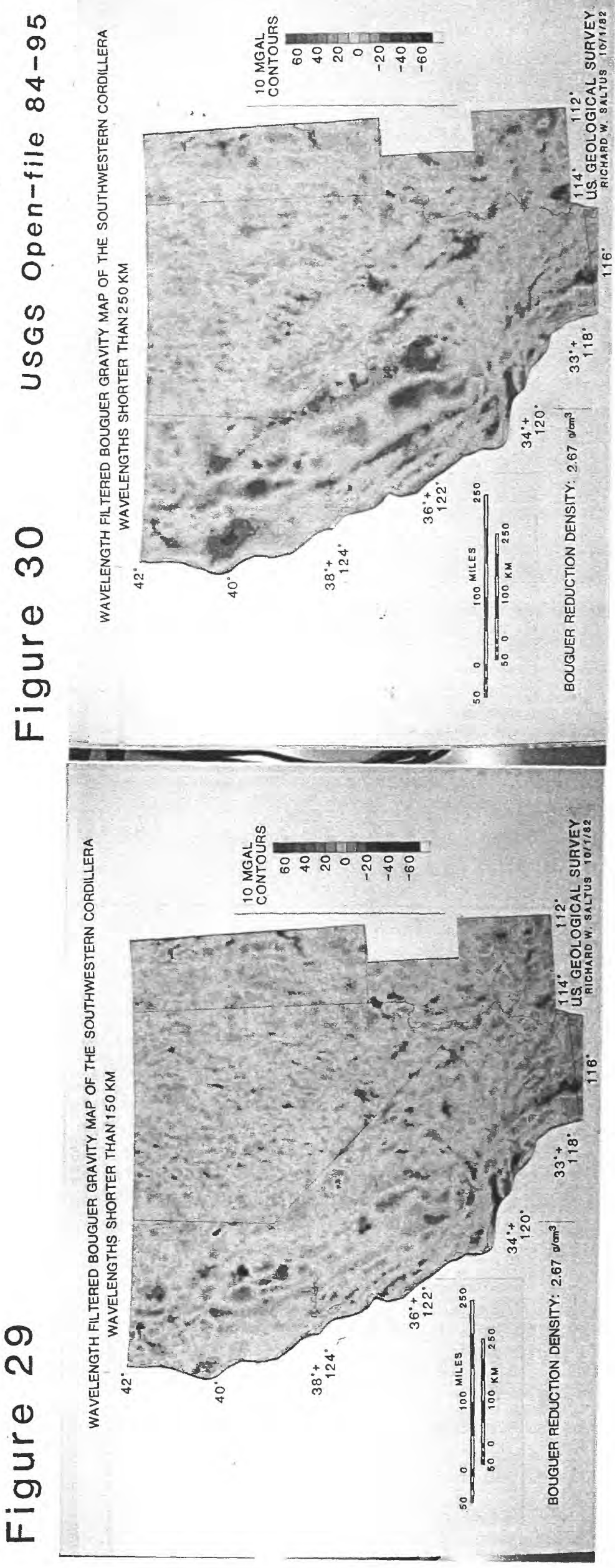

